\title{
PHARMACOKINETICS OF DOXYCYCLINE IN DUCKS WITH STEATOSIS DUE TO FORCE-FEEDING
}

\author{
Neno Bratoev, Aneliya Milanova, Ivelina Pavlova, Lubomir Lashev \\ Department of Pharmacology, Physiology and Physiological Chemistry, \\ Faculty of Veterinary Medicine, Trakia University, Bulgaria
}

Received 14 April 2016; Received in revised form 23 May 2016; Accepted 31 May 2016

\begin{abstract}
The pharmacokinetics of doxycycline was investigated in force-fed and normally fed ducks after single intravenous (i.v.) and oral (p.o.) administration at a dose of $15 \mathrm{mg} / \mathrm{kg}$ bw. Serum concentrations of the drug were determined by the HPLC method. Pharmacokinetic parameters were calculated using compartmental analysis. Serum concentrations of doxycycline after i.v. administration in both groups were not statistically different. The values of half-lives were $5.82 \pm 1.85 \mathrm{~h}$ and $6.06 \pm 5.51 \mathrm{~h}$ in normal and force-fed birds. The total body clearance was respectively $0.40 \pm 0.05 \mathrm{~L} / \mathrm{h} / \mathrm{kg}$ and $0.34 \pm 0.10 \mathrm{~L} / \mathrm{h} / \mathrm{kg}$, and volume of distribution $\left(\mathrm{V}_{\mathrm{ss}}\right)$ was $2.80 \pm 0.85 \mathrm{~L} / \mathrm{kg}$ and $2.18 \pm 0.89 \mathrm{~L} / \mathrm{kg}$. After p.o. administraton the maximum serum levels in the control group were $0.70 \pm 0.12 \mu \mathrm{g} / \mathrm{mL}$ and in force-fed birds were $1.93 \pm 0.32 \mu \mathrm{g} / \mathrm{mL}$, measured at $2.95 \pm 0.60 \mathrm{~h}$ and $1.45 \pm 0.24 \mathrm{~h}$, respectively. The values of absolute bioavailability were $18.89 \pm 6.48 \%$ and $37.58 \pm 13.63 \%$. Longer doxycycline retention in force-fed ducks was registered. Our data can be accepted as an information for possible prolonged retention of doxycycline in force fed ducks compared to normally fed ones.
\end{abstract}

Key words: doxycycline, ducks, force-feeding, pharmacokinetics

\section{INTRODUCTION}

Doxycycline (DOX), a broad spectrum bacteriostatic tetracycline derivative is active against Chlamydia spp., Rickettsia spp., Mycoplasma spp., Pasteurella multocida, E coli, and protozoa (1). It is preferred to other tetracyclines because of its higher oral absorption, high tissue concentrations and long persistence in orally treated animals (2). The pharmacokinetics of DOX is described in different bird species such as chickens $(2,3,4)$, turkeys $(5,6)$, ducks (7) and pigeons (8).

Fatty liver production is the process of forcefeeding ducks. This procedure, when carried out according to professional standards, does not induce diet-related pathological changes and the hepatic

Corresponding author: Prof. Lubomir D. Lashev, PhD

E-mail address: lashev@uni-sz.bg

Present address: Department of Pharmacology, Physiology and

Physiological Chemistry, Faculty of Veterinary Medicine,

Trakia University, Bulgaria

Phone: +35942699622

Copyright: (C) 2016 Bratoev N. This is an open-access article published under the terms of the Creative Commons Attribution License which permits unrestricted use, distribution, and reproduction in any medium, provided the original author and source are credited.

Competing Interests: The authors have declared that no competing interests exist.

Available Online First: 24 June 2016

Published on: 15 October 2016

http://dx.doi.org/10.1515/macvetrev-2016-0086 steatosis is reversible (9). Notwithstanding, it results in up to 5 -fold increase of the weight of liver. These changes are usually accompanied by alteration of liver function, decreasing of activity of enzymes such as proteases and increased AST, lipase blood levels and triglyceridemia $(10,11)$. During this period the birds change many physiological parameters and this can be accompanied by diseases with bacterial etiology. Their therapy often requires antibiotic use. Such type of changes can provoke variations in the drug disposition in case of necessary treatment (12). Although force feeding is not so prevalent as before, such animals need proper treatment and better understanding of the changes in order to design suitable dosage regimens. The data about the pharmacokinetics of antibacterials in force-fed ducks are more than insufficient. Thus the aim of the paper was to investigate the pharmacokinetics of doxycycline in force-fed ducks compared to normally fed birds.

\section{MATERIAL AND METHODS}

Animals

Two groups of 12 birds each were used. In the first experiment twelve ducks were used (6 
male and 6 female), eleven weeks old, weighing $2.83-4.36 \mathrm{~kg}$ at the time just before beginning of the fattening period, while in the second - twelve thirteen weeks old ducks (6 male and 6 female) at the end of fattening period, weighing 4.57-5.90 kg were used.

All of them were hybrids between male Muscovy and female Peking ducks. They were provided by a private farm and divided into subgroups, containing 6 birds each. Food and water were provided ad libitum, except 18 hours before the experiments when the food but not water was removed. Care and handling of animals were performed in accordance with the provisions for welfare of Regulation (EC) № 882/2004 of the European Parliament and of the Council of 29 April 2004 adopted by the Government of the Republic of Bulgaria with Ordinance № 20 from 01.11.2012. The experimental procedure was approved by the Ethical Committee at Trakia University, Stara Zagora (Reference No 65/18.10.2013).

\section{Drug}

Doxycycline hyclate $\left(\right.$ Biovet $^{\circledR}$, Peshtera, Bulgaria) was used as $5 \%$ water solution in distillated water. Oral treatment was performed with $1.33 \%$ water solution of doxycycline hyclate (Doxy-200 WS, Interchemie, Holland).

\section{Study design}

The experiment was divided into two parts. In the first part, ducks at age just before the beginning of force-feeding were used. They were randomly divided into two subgroups of 6 animals each ( 3 male and 3 female). In the second part of the experiment, 12 ducks at the end of the fattening period were included and also divided into two subgroups of 6 animals each ( 3 male and 3 female). The first two subgroups were treated intravenously (in the brachial vein) and the second - orally (by administering into the crop) at a dose of $15 \mathrm{mg} / \mathrm{kg}$ bw DOX.

Blood samples (each containing $0.5 \mathrm{~mL}$ ) were obtained from v. brachialis of each bird without an anticoagulant. After i.v. treatment, only the contralateral vein was used. Times for sampling after i.v. injection were at $0.083,0.25,0.5,1,3,6$, 9,12 и $24 \mathrm{~h}$, and following p.o. administration was at $0.25,0.5,1,3,6,9,12$ и $24 \mathrm{~h}$. All blood samples were centrifuged for $15 \mathrm{~min}$ at $1800 \mathrm{~g}$ and serum was separated. The obtained serum samples were stored at $-20{ }^{\circ} \mathrm{C}$ until analysis (not longer than two weeks).

\section{Analytical method}

Doxycycline concentrations were analysed by high-performance liquid chromatography (HPLC) 220 coupled with a PDA detector (13). The mobile phase consisted of acetonitrile, methanol, $0.02 \mathrm{M}$ oxalic acid, $0.02 \mathrm{M} \mathrm{Na}$ EDTA Triplex (20: 15: 64: 1, v/v/ $\mathrm{v} / \mathrm{v})$. The flow rate was $1.0 \mathrm{~mL} / \mathrm{min}$ and the PDA detector was set at $356 \mathrm{~nm}$. The data were analysed on the base of the area under the peak. Shortly, $15 \mu \mathrm{L}$ of the internal standard ( $11 \mu \mathrm{g} / \mathrm{mL}$ oxytertacycline) and $19.5 \mu \mathrm{L}$ trifluoroacetic acid were added to $150 \mu \mathrm{L}$ of serum samples. After vortexing, the samples were centrifuged for $10 \mathrm{~min}$ at $1800 \times \mathrm{g}$ at $22^{\circ} \mathrm{C}$. The supernatants were transferred to HPLC vials and $20 \mu \mathrm{L}$ were injected into the HPLC system (Thermo Fisher Scientific Inc., USA). The standard solutions of doxycycline were prepared in a serum from untreated animals at concentrations of 20, 10, $5,2.5,1,0.5,0.25$ and $0.125 \mu \mathrm{g} / \mathrm{mL}$. They were processed according to the described procedure. Oxytetracycline was added as an internal standard in the standard solutions and in the samples.

\section{Pharmacokinetic analysis}

The analysis was carried out by a specialized software (Phoenix 6.2.1; Pharsight, Mountain View, CA, USA). The following pharmacokinetic parameters were computed: $\mathrm{k}_{12}$ and $\mathrm{k}_{21}$ - distribution rate constant from the central to the peripheral compartment and from peripheral to central compartment; $t_{1 / 2 \alpha}$ - distribution half-life; $t_{1 / 2 \beta}$ elimination half-life after i.v. administration; $t_{1 / 2 \mathrm{el}}$ elimination half-life after p.o. administration; $\mathrm{Cl}_{\mathrm{B}}$ - total body clearance; $\mathrm{V}_{\mathrm{ss}}$ - volume of distribution at steady state; $\mathrm{Vd}_{\text {area }}$ - volume of distribution; $\mathrm{AUC}_{0 \rightarrow \infty}$ - area under the concentration-time curves; MRT - mean residence time; $\mathrm{C}_{\max }$ - maximum serum levels; $\mathrm{T}_{\max }$ - time of $\mathrm{C}_{\max }$. Bioavailability $(\mathrm{F})$ was calculated according to the following equation:

$$
\mathrm{F}(\%)=(\text { AUCp.o./AUCi.v. }) \times 100
$$

\section{Statistical analysis}

The results are expressed as mean values $\pm \mathrm{SD}$. Descriptive statistics was performed with Statistica for Windows (Statistica 6.0.1, USA); $\mathrm{p}<0.05$ was considered to be significant.

\section{RESULTS}

Doxycycline serum concentrations after both administration roads in normally and force-fed ducks are presented in Figure 1, and the values of pharmacokinetic parameters in Table 1.

The data after i.v. administrations were not significantly different between both groups. Shorter distribution half-life was calculated in the force-fed 


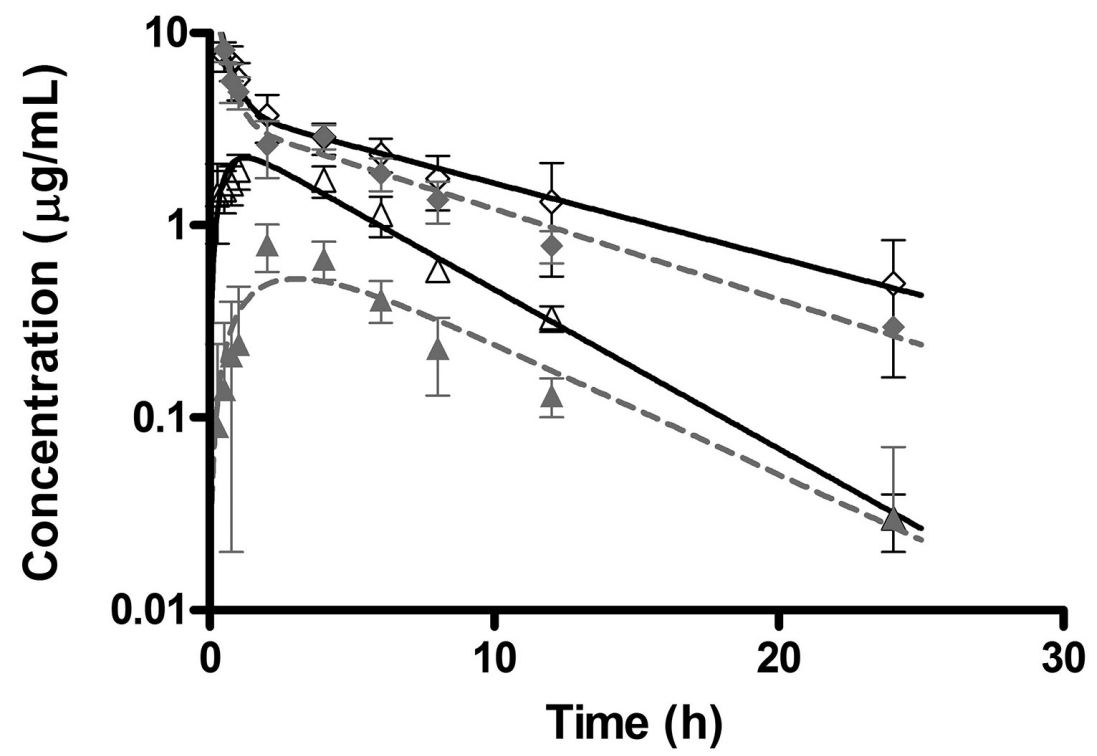

Figure 1. Serum concentrations of doxycycline (mean \pm SD) after i.v. ( $\left.{ }^{\circledR}\right)$ and p.o. (rp) administration in ducks before (---) and after force-feeding (-) at a dose of $15 \mathrm{mg} / \mathrm{kg}$

ducks, but the values of distribution volumes were not statistically different. The elimination half-life showed tendency for prolongation, with higher values in force-fed birds. The same dependence existed for the values of MRT. The total body clearance was insignificantly slower. After p.o. administration the force-fed ducks absorbed faster and more completely DOX. Its maximum serum levels were higher and were measured earlier in this group of birds. Similarly to the i.v. injection, the values of $t_{1 / 2 \beta}$ were not statistically different between normally and force-fed ducks. The values of AUC and absolute bioavailability were twice higher in the force-fed ducks if compared to control birds.

Table 1. Selected pharmacokinetic parameters of doxycycline in ducks, after intravenous or oral administration at dose of $15 \mathrm{mg} / \mathrm{kg}($ mean $\pm \mathrm{SD})$

\begin{tabular}{cccccc}
\hline Parameters & Units & \multicolumn{2}{c}{ After i.v. administration } & \multicolumn{2}{c}{ After p.o. administration } \\
\cline { 3 - 5 } & & Before force-feeding & With steatosis & Before force-feeding & Whit steatosis \\
$\mathrm{t}_{1 / 2 \alpha}$ & $\mathrm{h}$ & $0.25 \pm 0.05$ & $0.16 \pm 0.09^{*}$ & & \\
$\mathrm{t}_{1 / 2 \beta} / \mathrm{t}_{1 / 2 \mathrm{el}}$ & $\mathrm{h}$ & $5.82 \pm 1.85$ & $6.06 \pm 5.41$ & $4.01 \pm 1.82$ & \\
$\mathrm{Cl}_{\mathrm{B}}$ & $\mathrm{L} / \mathrm{h} / \mathrm{kg}$ & $0.40 \pm 0.05$ & $0.34 \pm 0.10$ & & \\
$\mathrm{Vd}_{\text {area }}$ & $\mathrm{L} / \mathrm{kg}$ & $3.97 \pm 1.27$ & $3.01 \pm 0.66$ & & \\
$\mathrm{~V}_{\mathrm{ss}}$ & $\mathrm{L} / \mathrm{kg}$ & $2.80 \pm 0.85$ & $2.18 \pm 0.89$ & & \\
$\mathrm{AUC}_{0 \rightarrow \infty}$ & $\mu \mathrm{gh} / \mathrm{mL}$ & $38.12 \pm 4.82$ & $49.1 \pm 23.06$ & $6.97 \pm 1.65$ & $16.09 \pm 2.16^{*}$ \\
$\mathrm{MRT}$ & $\mathrm{h}$ & $7.03 \pm 1.93$ & $8.04 \pm 7.74$ & $10.92 \pm 5.30$ & $10.34 \pm 2.57$ \\
$\mathrm{C}_{\max }$ & $\mu \mathrm{g} / \mathrm{mL}$ & & & $0.7 \pm 0.12$ & $1.93 \pm 0.32^{*}$ \\
$\mathrm{~T}_{\max }$ & $\mathrm{h}$ & & & $2.95 \pm 0.60$ & $1.45 \pm 0.24^{*}$ \\
$\mathrm{t}_{1 / 2 \mathrm{abs}}$ & $\mathrm{h}$ & & & $1.42 \pm 0.66$ & $0.37 \pm 0.11^{*}$ \\
$\mathrm{~F}$ & $\%$ & & 6 & $18.89 \pm 6.48$ & $37.58 \pm 13.63^{*}$ \\
$\mathrm{n}$ & & & & 6 & 6 \\
\hline
\end{tabular}

* Statistically significant difference between ducks before force-feeding and whit steatosis at $p<0.05$

$\mathrm{t}_{1 / 2 \alpha}$ - distribution half-life; $\mathrm{t}_{1 / 2 \beta}$ - elimination half-life after i.v. administration; $\mathrm{t}_{1 / 2 \mathrm{el}}$ - elimination half-life after p.o. administration; $\mathrm{t}_{1 / 2 a b s}$ - absorption half-life after p.o. administration $\mathrm{Cl}_{\mathrm{B}}$ - total body clearance; $\mathrm{V}_{\mathrm{ss}}-$ volume of distribution at steady state; $\mathrm{Vd}_{\text {area }}-$ volume of distribution; $\mathrm{AUC}_{0 \rightarrow \infty}$ - area under the concentration-time curves; MRT - mean residence time; $\mathrm{C}_{\max }-$ maximum serum levels; $\mathrm{T}_{\max }-$ time of $\mathrm{C}_{\max } ; \mathrm{F}$ - bioavailability; $\mathrm{n}$ - number of birds in a group. 


\section{DISCUSSION}

Doxycycline is one of the most often used tetracycline antibiotics in poultry farming. Its pharmacokinetics is well described in healthy chickens $(2,14,15)$, turkeys (6), ducks (7), pigeons as well as wild bird species (8) and the dosage regimens are defined.

The steatosis as a result from force-feeding was a reason for significant changes of the liver function, which could be followed by different absorption, distribution and elimination of substances in accordance with theirchemical structure and behavior in the body (12). The values of some biochemical parameters were statistically significantly increased after force-feeding: holesterol (from $4.74 \pm 0.61$ to $13.48 \pm 2.84 \mathrm{mmol} / \mathrm{L}$ ), triglycerides (from $0.44 \pm 0.10$ to $2.04 \pm 1.24 \mathrm{mmol} / \mathrm{L}$ ), bilirubin had almost doubled values and $\mathrm{LDH}$ (from $648 \pm 206 \mathrm{U} / \mathrm{L}$ to $1500 \pm 783 \mathrm{U} / \mathrm{L}$ ) as it was found in our previous work (12). Other investigation revealed that bromosulfophtaleine and indocyanine green, compounds used for evaluation of liver function, had retarded elimination and higher volume of distribution in force-fed ducks, demonstrating possible changes in biliary excretion of drugs (16).

Up to now, data about the pharmacokinetics of doxycycline in force-fed ducks is not known. In our case, the differences between the control and experimental groups were the diet and the age of two weeks. That is why the alterations found in the pharmacokinetics in force-fed ducks were linked to the diet and the provoked changes in the liver. Absence of significant changes in the values of total body clearance and $\mathrm{Vd}_{\text {area }}$ determined similar elimination half-life in both groups of ducks after intravenous administration. Significantly higher distribution rate constant in the normally fed birds demonstrate faster distribution of doxycycline in this group of animals. The values of the ratio of the rate constants, characterizing the transport of doxycycline between two compartments, were similar and showed faster penetration of the antibiotic from the central to the second deep compartment. All the results for distribution were different from the data for enrofloxacin in similar experiment with ducks (12). These differences can be discussed in relation to the properties of the compounds such as $\mathrm{pKa}$ and $\mathrm{pH}$, their lipophilicity. Another explanation can be found in the metabolism of these compounds. Doxycycline is not metabolized and it is excreted mainly via the bile. In contrary, enrofloxacin is metabolized to ciprofloxacin and other metabolites which are excreted via urine and bile $(17,18)$. Buechler and Weiss (17) reviewed the changes in liver disposition and pharmacokinetics of biliary excreted drugs in steatosis. The cited authors attributed the observed variations to the expression and function of enzymes from the $\mathrm{I}^{\mathrm{st}}$ and II ${ }^{\text {nd }}$ phase of metabolism together with transporter proteins in such liver disorders. Alteration of liver enzymes from the CYP450 family that participate in the metabolism of enrofloxacin can be a reason for slower elimination of the fluoroquinolone in forcefed ducks $(12,18)$.

After oral treatment in force-fed ducks, statistically significant lower values of $t_{1 / 2 a b s}, T_{\max }$ and higher levels of $\mathrm{C}_{\max }$ showed that this diet leads to faster and higher absorption of doxycycline. This data was in accordance with the higher values of AUC, absolute and relative bioavailability. The observed changes demonstrate that the absorption of doxycycline can be increased in ducks with steatosis and higher concentrations of the antibiotic in the liver with prolonged withdrawal time for this tissue can be expected. The highly lipophilic character of doxycycline, together with increased contents of holesterol and triglycerides, can also explain the higher $\mathrm{C}_{\max }$ and bioavailability in this group of ducks (19). Retention of bilirubin in ducks with steatosis also deserves attention and further studies of antibiotic transport from hepatocytes into the bile via transporter proteins are required (18). Further studies are required to evaluate the differences in tissue disposition of this drug in force-fed birds.

Doxycycline is used in treatment of Escherichia coli, Pasteurella spp., Mycoplasma spp. and Staphylococcus spp. infections in ducks. Its administration requires MIC determination and according to our results oral dose of $15 \mathrm{mg} / \mathrm{kg}$ can be high enough to treat only very susceptible pathogenic bacteria with MIC lower than $0.5 \mu \mathrm{g} / \mathrm{ml}$. Although higher concentrations of doxycycline were determined in ducks with steatosis, better efficacy of treatment can be achieved with higher doses that can guarantee concentrations above MIC during at least $80 \%$ of the dosage interval (20).

\section{CONCLUSION}

As a conclusion, ducks with fatty liver better absorb doxycycline and show a tendency for a slower elimination compared to normally fed. The observed differences can be accepted as an information for possible prolonged retention of doxycycline in force fed ducks compared to normally fed. 
Pharmacokinetics of doxycycline in ducks with steatosis due to force-feeding

\section{REFERENCES}

1. Pijpers, A., Van Klingeren, B., Schoevers, E.J., Verheijden, J.H.M., Van Miert, A.S. (1989). In vitro activity of five tetracyclines and some other antimicrobial agents four porcine respiratory tract pathogens. J. Vet. Pharmacol. Ther. 12, 267-276. http://dx.doi.org/10.1111/j.1365-2885.1989.tb00670.x PMid:2810475

2. Anadón, A., Martínez-Larra-aga, M.R., Diaz, M.J., Bringas, P., Fernandez, M.C., Fernandez-Cruz, M.L., Iturbe, J., Martínez, M.A. (1994). Pharmacokinetics of doxycycline in broiler chickens. Avian Pathol. 23, 79-90.

http://dx.doi.org/10.1080/03079459408418976 PMid:18671073

3. Poapolathep, A., Poapolathep, S., Imsilp, K., Noonpugdee, C., Klangkaew, N., Kusujarit, N., Tirawattanawanich, C., Subsinsoonthon, B. (2005). Pharmacokinetics and bioavailability of doxycycline in Thai native chickens. J. Thai. Vet. Med. Assoc. 56, 59-65.

4. Yang, F., Li, GH., Meng, X.B., Wang, L.Q., Huang, X.H., Shan, Q., Zeng, D.P., Ding, H.Z., Zeng, Z.L. (2012). Pharmacokinetic interactions of flunixin meglumine and doxycycline in broiler chickens. J. Vet. Pharmacol. Ther. 36, 85-88.

http://dx.doi.org/10.1111/j.1365-2885.2012.01382.x PMid:22292913

5. Küng, K., Wanner, M. (1994). Pharmacokinetics of Doxycycline in turkeys and comparison between feed and water medication. Archiv für Geflügelkunde 58, 84-88.

6. Santos, M.D., Vermeersch, H., Remon, J., Schelkens, M., Backer, P., Van Bree, H.J., Ducatelle, R., Haesebrouck, F. (1996). Pharmacokinetics and bioavailability of doxycycline in turkeys J. Vet. Pharmacol. Ther. 19, 274-280. http://dx.doi.org/10.1111/j.1365-2885.1996.tb00049.x

7. Yang, F., Sun, N., Zhao, Z.S., Wang, G.Y., Wang, M.F. (2015). Pharmacokinetics of doxycycline after a single intravenous, oral or intramuscular dose in Muscovy ducks (Cairina moschata). British Poultry Sci. 56, 137-142.

http://dx.doi.org/10.1080/00071668.2014.989488 PMid:25411077

8. Dorrestein, G., Weling, J., Haagsma, N. (1990). Pharmacokinetic differences for doxycycline between racing pigeon (Columba livia) and collared doves (Streptopelis decaocto) and the effect of a salmonella infection. In VII. Tagung der Fachgroupe „Geflugelkrankheiten“ (pp. 132-143), In Verbindung dem Institut für Geflugelkrankheiten der LudvigMaximilians-Universitet, München, Germany,
9. Bernard, P.G., Bengone, T, Prehn, D., Durand, S., Labie, C., Benard, P. (2006). Physiology of ducks during force-feeding: study of hepatic steatosis. Bulletin de 1'Academie Vétérinaire de France 159, 43-54.

10. Bogin, E., Avidar, Y., Merom, M., Israeli, B., Malkinson, M., Sobak, S., Kudler, Y. (1984). Biochemical changes associated whit fatty liver in geese. Avian Pathol. 13, 683-901.

http://dx.doi.org/10.1080/03079458408418566

PMid:18766879

11. Awde, S., Marty-Gasset, N., Wilkesman, J., Remingnon, H. (2013). Proteolytic activity alterations resulting from force-feeding in Muscovy and Pekin ducks. Poultry Sci. 92, 2997-3002.

http://dx.doi.org/10.3382/ps.2013-03195

PMid:24135604

12. Bratoev, N., Lashev, L. (2014). Pharmacokinetics of enrofloxacin in ducks with steatosis after forcefeeding. VII- conference of the Bulgarian focal center of EFSA, October 2014, Sofia, Bugaria.

13. Baert, K., Croubels, S., Gasthuys, F., De Busser, J., De Backer, P. (2001). Pharmacokinetics and oral bioavailability of a doxycycline formulation (DOXYCYCLINE 75\%) in nonfasted young pigs. J. Vet. Pharmacol. Ther. 23, 45-48.

14. El-Gendi, A.Y.I., Aziza, M.A., Amer, M.M., Kamel, G.M. (2010). Pharmacokinetic and tissue distribution of doxycycline in broiler chickens pre-treated with either: Diclazuril or Halofuginone. Food and Chem. Toxicol. 48, 3209-3214.

http://dx.doi.org/10.1016/j.fct.2010.08.024 PMid:20736042

15. Yang, F., Si, H,B., Wang, Z.S., Zhao, B. H., Zhou, B. H., Hao, X. Q. (2016). Pharmackinetics of doxycycline in laying hens after intravenous and oral administration. Britsh poultry sci.

http://dx.doi.org/10.1080/00071668.2016.1184228 PMid:27137900

16. Bengone-Ndong, T., Benard, G., Prehn, D., Colas, E., Grimm, F., Benard, P. (1996). Etude de la cinetique de la bromosulfonephthaleine et du vert d'indocyanine chez le canard: determination de la linearite. Revue. Méd. Vét. 147, 75-80.

17.Slana, M., Pahor, V., Cvitkovič Maričič, L, Sollner-Dolenc, M. (2014). Excretion pattern of enrofloxacin after oral treatment of chicken broilers. 37, 611-614.

http://dx.doi.org/10.1111/jvp.12130

18. Buechler, C, Weiss, T.S. (2011). Does hepatic steatosis affect drug metabolizing enzymes in the liver? Curr. Drug Metab. 12, 24-34. http://dx.doi.org/10.2174/138920011794520035 
19. Liu, Y., Ramamurthy, N., Marecek, J., Lee, H.M., Chen, J.L., Ryan, M.E., Rifkin, B.R., Golub, L.M. (2001). The lipophilicity, pharmacokinetics, and cellular uptake of different chemically-modified tetracyclines (CMTs). Curr. Med. Chem. 8, 243-252. http://dx.doi.org/10.2174/0929867013373525 PMid:11172678
20. Mckellar, Q., Sanchez Bruni, A. S. F., Jones, D. G. (2004) Pharmacokinetic /pharmacodynamic relationships of antimicrobial drugs used in veterinary medicine. J. Vet. Pharmacol. Therap. 27, 503-514. http://dx.doi.org/10.1111/j.1365-2885.2004.00603.x PMid:15601444 